\title{
FLORISTIC COMPOSITION OF TWO WETLAND FORESTS IN ARAGUAIAN PLAIN, STATE OF TOCANTINS, BRAZIL, AND COMPARISON WITH OTHER AREAS
}

\author{
Sebastião Venâncio Martins², Elizabeth Rodrigues Brito ${ }^{3}$, Ary Teixeira de Oliveira Filho ${ }^{4}$, Alexandre \\ Francisco da Silva ${ }^{5}$ Elias Silva ${ }^{2}$
}

\begin{abstract}
Seasonally inundated native forest fragments ("ipucas") located in natural landform depression swales of the Araguaian Plain are currently under land use pressure. Their composition needs to be better understood to guarantee their protection. This comparative study of fragments under different land use conditions was carried out at Lago Verde Farm, Lagoa da Confusão,Tocantins, Brazil. The location coordinates are UTM 643586 and 644060 East and 8792795 and 8799167 North. This study aimed to first analyze and compare the floristic composition of two seasonally inundated forest fragments of approximately one hectare each. The first is located in an intact (without human intervention) Gramineous-Woody Savanna region and the second in a rice cultivation region. The floristic composition of both fragments was then compared to that of other wetland forests located in the Northern, Central Western and Southeastern regions of Brazil.All the floristic compositions are affected by seasonal flooding and soil water saturation. The floristic inventory used a census method that sampled all trees and shrubs with perimeter at $1.30 \mathrm{~m}$ from soil $(\mathrm{PAP})=15 \mathrm{~cm}$; 665 individuals, 33 families and 49 species were recorded for the intact region and 807 individuals, 35 families and 70 species for the altered region fragment. The values of $\mathrm{H}^{\prime}=0.806$ (Shannon-Weaver) and $\mathrm{J}=3.44$ nats /individual (equability) for the fragment in the region affected by rice cultivation are considered high compared to the intact region fragment values $\left(H^{\prime}=0.761\right.$ and $\left.\mathrm{J}=2.97\right)$. Families contributing to floristic richness in the altered region fragment were Fabaceae (9 species), Vochysiaceae (6) and Annonaceae (4). In the intact region fragment, Fabaceae also presented the largest number of species (8) followed by Arecaceae, Chrysobalanaceae and Vochysiaceae (3 each). When comparing the forests from various regions in Brazil, floristic similarity was found to be small. Greater similarity was found when indices for the two Lagoa da Confusão fragments were compared to riparian forests located in the Federal District of Brasilia.
\end{abstract}

Keywords: Floodplain forest, ipuca and forest fragment.

\section{COMPOSIÇÃO FLORISTICA DE DUAS FLORESTAS INUNDÁVEIS NA PLANÍCIE DO ARAGUAIA, ESTADO DO TOCANTINS, BRASIL, E COMPARAÇÃO COM OUTRAS ÁREAS}

RESUMO - Os fragmentos naturais de florestas inundáveis conhecidos como Ipucas localizam-se na planície do Araguaia, sob a forma de depressões naturais, estando atualmente sob forte pressão antrópica. Este estudo foi desenvolvido na fazenda Lago Verde, Lagoa da Confusão em Tocantins, entre as coordenadas UTM 643586 e 644060 leste e 8792795 e 8799167 norte. Os objetivos deste trabalho foram analisar e comparar a composição florística de dois fragmentos de florestas inundáveis de aproximadamente 1 ha cada, sendo um inserido

\footnotetext{
${ }^{1}$ Recebido em 26.05.2006 e aceito para publicação em 18.12.2007.

${ }^{2}$ Departamento de Engenharia Florestal da UFV, Viçosa-MG. E-mail : <venancio@ufv.br>.

${ }^{3}$ Programa de Pós-Graduação em Ciência Florestal da UFV e Instituto Natureza do Tocantins, Palmas-TO. E-mail : <erbrito@bol.com.br>.

${ }^{4}$ Departamento de Ciências Florestais da Universidade Federal de Lavras. E-mail : <ary@ufla.br>.

${ }^{5}$ In Memorian.
} 
em área de Savana Gramíneo-Lenhosa sem intervenção antrópica e outro em área de orizicultura, com outras florestas também sob influência de inundações sazonais e, ou, saturação hídrica do solo das Regiões Norte, Centro-Oeste e Sudeste. O levantamento florístico foi realizado através do método de Censo, em que foram amostrados todos os indivíduos arbustivo-arbóreos com perímetro a 1,30 m do solo $(P A P)=15 \mathrm{~cm}$. Como resultado, foram apresentados 807 indivíduos, 35 famílias e 70 espécies na área antropizada e 665 indivíduos, 33 famílias e 49 espécies na área preservada. Os valores de $H^{\prime}$ (Shannon-Weaver) e J (equabilidade) da área que está sob influência da orizicultura, 3,44 nats/indivíduo e 0,806, respectivamente, podem ser considerados altos em relação ao outro fragmento, onde os valores foram de 2,97 nats/indivíduo e 0,761. As famílias que contribuíram para a riqueza florística na floresta inundável com intervenção antrópica foram Fabaceae (9), Vochysiaceae (6) e Annonaceae (4). Na floresta inundável em área preservada, Fabaceae também apresentou maior riqueza, com oito espécies, seguidas de Arecaceae, Chrysobalanaceae e Vochysiaceae (3) cada. A similaridade florística foi baixa entre todas as florestas comparadas, porém maior semelhança foi encontrada entre florestas ripárias do Distrito Federal e entre as duas florestas inundáveis deste estudo.

Palavras-chave: Florestas inundáveis, Ipucas e fragmentos florestais.

\section{INTRODUCTION}

The Brazilian cerrado occurs as a contiguous land area covering the states of Goiás and Tocantins, the Federal District of Brasilia, and parts of the states of Bahia, Maranhão, Mato Grosso, Mato Grosso do Sul, Minas Gerais, Piauí, Rondônia and São Paulo. In noncontiguous areas, it also occurs in the northern parts of Ceará, Pernambuco, Amapá, Amazonas, Pará and Roraima. It is also found as small "islands" in the southern state of Paraná (EITEN, 1994). Overall, the Brazilian cerrado covers approximately 2 million km² of Brazil and is surpassed only by the Amazon Forest of approximately 3.5 million km² (RATTER et al., 1997).

A comprehensive knowledge about the cerrado floras is of fundamental importance to define representative areas for this biome. Given the pressures of rapidly expanding land use, this information should help prioritize conservation projects and rational forest management (FELFILI et al., 1993).

A transition area between cerrado and the Amazon forest dominates the Araguaia Plain between the states of Tocantins and Mato Grosso. It periodically floods during the rainy season, with inundation lasting from four to five months. Bananal Island (EITEN,1985) is the most representative region of this $600,000 \mathrm{~km}^{2}$ area. Despite being a transition between two biomes, for legal purposes this area has been included under the heading of cerrado. This is according to the classification system adopted by the Brazilian Institute for Geography and Statistics - IBGE (VELOSO et al., 1991). It includes Gramineous-Woody cerrado, Tree-Covered cerrado,
Cerrado Parklands and Forested Cerrado. Although these are the predominant landscape types, smaller insular forest types also occur. These include gallery forests and a plant community type of seasonally inundated forest regionally known as "ipuca” or "impuca” (EITEN, 1985).

Ipucas are restricted to well-defined floodplain conditions in the state of Tocantins, occurring only in natural depressions. Being lowlands, they are easily inundated and retain water longer than the surrounding landscape. As isolated fragments, they feature their own peculiar structural and physiognomic floristics compared to surrounding vegetation types. At the study area the ipuca fragments occur within sub formations of broad field physiognomies regionally called "varjões". Eiten (1985) considers the varjão as belonging to a type of Pantanal (Central Brazil swampland) characterized by non-forested terrain and annually submersed or subject to shallow flooding for four to five months, usually from December until March or April. The varjões become very dry during the drought season (June to September) and, in some places, occur in termite hill-pocked fields called murundus.

The most important studies on Tocantins vegetation of the few currently available are those by Rizzo (1981), RADAMBRASIL (1981), Ratter (1987) and Mileski(1994). Available publications and herbarium collections reveal that very little is known about this state's botany. Therefore, our first objective was to make an inventory of the floristics of two naturally occurring floodplain forest fragments, an intact area without land use and

\section{R. Árvore, Viçosa-MG, v.32, n.1, p.129-141, 2008}


the other one, an irrigated rice cultivation region. Both are located in the Municipal District of Lagoa da Confusão, Tocantins. Both floristics were then compared to forests under the influence of seasonal flooding or water saturation (or both), found in Northern, Central Western and Southeastern Brazil.

To find suitable comparisons, previous studies were reviewed including research on swampland, floodplain, and riparian forests. Similar to the study area, these types are influenced by year-round or seasonal presence of water in soil.

\section{MATERIALAND METHODS}

\subsection{Study area}

This study was carried out in the municipal district of Lagoa da Confusão, at a property locally known as Lagoa Verde Farm. It lies between coordinates UTM: 643586 to 655060 East and 8792795 to 8799167 North (MARTINS et al., 2002). The study area is near two federally protected areas: Araguaia National Park and Araguaia Indigenous Park, both in Tocantins. The average altitude of this plain is $180 \mathrm{~m}$, and the average annual temperature is $24^{\circ} \mathrm{C}$. The average annual precipitation is $1700 \mathrm{~mm}$, which mostly occurs from October to April. According to Thornthwaite-Mather classification, the climate of the area is type B2rA'a': humid climate with little or no water deficit. The soils of the area include patches of gleisols (Brazilian soil type) underlying the fragments of native seasonally inundated forests and plintosols for the remaining area. These soils are shallow and strongly affected by the water table (SEPLAN/TO, 2002). Vegetation types found in this area are cerrado, Riparian Forests, and fragments of Seasonally Inundated Forests. Land use in this region has been growing since the late 1960s and especially during the 1970s and 1980s. Its level topography is ideal for agricultural mechanization and cattle grazing.

\subsection{Floristic inventory}

Two one-hectare forest fragments were chosen for the study. The first is located in an area of intact Gramineous-Woody Cerrado, and the second is located in an irrigated rice cultivation area. The two fragments are very similar in terms of natural regeneration. Although Gramineous-Woody cerrado surrounding the second fragment was removed, the seasonally inundated vegetation of the hectare itself was left intact. That has allowed this fragment to escape direct man-caused disturbances such as fire and cattle grazing. Only fragment borders had been affected by the surrounding rice cultivation.

A plant census was performed in each fragment by numerically marking and taxonomically identifying all trees and shrubs with perimeter at $1.30 \mathrm{~m}$ from soil $(\mathrm{PAP})=15 \mathrm{~cm}$. Botanical samples were identified by comparing materials to herbarium collections located at the Universidade Federal de Viçosa, Universidade Nacional de Brasilia and Universidade Federa de Lavras.

The scientific names and respective authors were confirmed and updated by bibliographic research and by using the Missouri Botanical Garden website (http://www.mobot.org/w3t/search/vast.html). The classification system used was APG II (2003).

\subsection{Soil description}

To describe soils underlying the two selected fragments, a sample composed of the upper surface profile was collected within each fragment. Ten simple samples were collected at 0 to $20 \mathrm{~cm}$ depth. Using EMPRAPA (1979) methodology, the samples were submitted to chemical and texture analyses at the Soil Laboratory of the UFV.

\subsection{Floristic analysis}

To compare the two Lagoa da Confusão fragments to wetland forests elsewhere in Brazil, 19 other floristic studies were selected. They were chosen because all include both floristic and phyto-sociological data. The first step to analyze floristic similarity was to develop a binary matrix listing presence or absence of all the shrubby-woody species occurring in the selected studies. The matrix also included results of the botanical census conducted for the two Lagoa da Confusão seasonally inundated forests. This presence/absence matrix was used to construct a Jaccard Index (MUELLER-DOMBOIS and ELLENBERG 1974).

Grouping analysis (UPGMA) was used to analyze floristic similarity among the 21 forests. Groups are determined by using the arithmetic average of elements, generating a dendrogram in which the values of ordinates express similarity among the objects indicated by the abscissas (SNEATH and SOKAL, 1973).

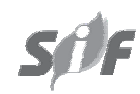

R. Árvore, Viçosa-MG, v.32, n.1, p.129-141, 2008 
To interpret the floristic diversity of the seasonally inundated forests, the same indexes were used as employed in the compared studies: Shannon diversity index (H') and Pielou index of uniformity (J') (PIELOU, 1975). All analyses were accomplished using the program FITOPAC (SHEPHERD, 1996).

\section{RESULTS AND DISCUSSION}

\subsection{Soil analysis}

The chemical and textural analyses for the two fragment soils are presented in Table 1. Both soils are dystrophic with high aluminum levels and low base saturation. However, the forest fragment soil in the irrigated rice region is, in agronomic terms, slightly better than the soils underlying the intact region's fragment. The rice cultivation region fragment has higher values of base saturation and $\mathrm{pH}$ in water. The difference is slight and may be due to annual chemical fertilizing and liming applied for more than a decade to the surrounding rice cultivations. Considering that the fragments lie within terrain depressions, it is likely that substantial amounts of fertilizers and lime drain into them at the end of the rainy season. The textural analysis indicates that soils from the two fragments vary from clay to clay loam.

\subsection{Floristic composition}

The combined inventories for the two forest fragments totaled 1472 individuals, 43 families and 95 species. The rice cultivation region fragment had 807 individuals with 35 families, 57 genera and 70 species and the intact region fragment had 665 individuals with 33 families, 44 genera and 49 species (one not identified) (Table 2).

The families most contributing to floristic richness in the altered region fragment were Fabaceae with 9 species $(12.9 \%)$, Vochysiaceae with 6 species $(8.6 \%)$, Annonaceae with 4 species (5.7\%), and Bignoniaceae, Meliaceae, Myrtaceae, Sapindaceae and Malvaceae with 3 species, each (4.3\%). The families with highest density were Vochysiaceae (104 individuals), Chrysobalanaceae (90), Urticaceae (70) and Malpighiaceae (66). The largest contribution for Vochysiaceae came from species Qualea multiflor (71 individuals). Hirtella recemosa contributed the most individuals (88) for family Chrysobalanaceae, Cecropia pachystachya (70) for Urticaceae, and Byrsonim intermedia (60) for Malpighiaceae.

\section{R. Árvore, Viçosa-MG, v.32, n.1, p.129-141, 2008}

Table 1 - Results from chemical and granulometric soil analyses for two seasonally inundated forest fragments in the Municipal District of Lagoa da Confusao, Tocantins, Brazil. A: seasonally inundated forest in a rice-cultivated region; B: seasonally inundated forest in intact (unaltered) region. (SB: sum of exchangeable bases; t: effective cation exchange capacity; $\mathrm{T}$ : cation exchange capacity at $\mathrm{pH}$ 7.0; V: base saturation; $\mathrm{m}$ : aluminum saturation

Tabela 1 - Resultado das análises químicas e granulométricas de solo dos dois fragmentos de florestas inundáveis no município de Lagoa da Confusão, Tocantins. A: floresta inundável em área antropizada; $B$ : floresta inundável em área preservada (SB: soma de bases trocáveis; $t$ : capacidade de troca catiônica efetiva; T: capacidade de troca cationica em $\mathrm{pH} 7 ; \mathrm{V}$ : saturação por bases; e m: saturação por Alumínio)

\begin{tabular}{|c|c|c|}
\hline Parameter & A & B \\
\hline$\overline{P\left(m g . \mathrm{dm}^{3}\right)}$ & 0.7 & 1.4 \\
\hline P-remaining (mg.l) & 11.1 & 7.0 \\
\hline $\mathrm{K}^{+}\left(\mathrm{mg} \cdot \mathrm{dm}^{-3}\right)$ & 73 & 36 \\
\hline $\mathrm{Ca}^{++}\left(\mathrm{cmol}_{\mathrm{c}} \cdot \mathrm{dm}^{-3}\right)$ & 0.97 & 1.04 \\
\hline 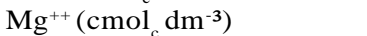 & 1.33 & 1.09 \\
\hline $\mathrm{Al}^{+++}\left(\mathrm{cmol}_{c} \mathrm{dm}^{-3}\right)$ & 0.60 & 1.20 \\
\hline $\mathrm{H}^{+}+\mathrm{Al}^{+++}\left(\mathrm{cmol}_{\mathrm{c}} \mathrm{dm}^{-3}\right)$ & 9.1 & 14.9 \\
\hline $\begin{array}{l}\text { SB - sum of exchangeable } \\
\text { bases }\left(\mathrm{cmol} \cdot \mathrm{dm}^{-3}\right)\end{array}$ & 2.49 & 2.22 \\
\hline $\mathrm{t}\left(\mathrm{cmol}_{\mathrm{c}} \mathrm{dm}^{\mathrm{c}}{ }^{-3}\right)$ & 3.09 & 3.42 \\
\hline $\mathrm{T}\left(\mathrm{cmol}_{\mathrm{c}} \cdot \mathrm{dm}^{-3}\right)$ & 11.59 & 17.12 \\
\hline V (\%) & 21.05 & 13.0 \\
\hline m (\%) & 19.4 & 35.1 \\
\hline pH (water) & 5.59 & 4.24 \\
\hline Coarse sand (dag.kg $\left.{ }^{-1}\right)$ & 13 & 21 \\
\hline Fine sand (dag. $\mathrm{kg}^{-1}$ ) & 14 & 23 \\
\hline Silt (dag. $\mathrm{kg}^{-1}$ ) & 21 & 23 \\
\hline Clay (dag. $\mathrm{kg}^{-1}$ ) & 52 & 33 \\
\hline Textural class & Clay & Clay loam \\
\hline
\end{tabular}

As for the intact region fragment, the richest family represented was also Fabaceae, with 8 species (16.3\% of total), followed by Arecaceae, Chrysobalanaceae and Vochysiaceae, with 3 species each (6.1\%). Five families stood out in relation to the total of inventoried individuals: Fabaceae (161), Ebenaceae (67), Annonaceae (48), Rutaceae (44) and Clusiaceae (41). The prominence of the family Fabaceae (161 individuals) was due mainly to Sclerolobium paniculatum var. rubiginosum with138 individuals. Diospyros guianensi with 67 individuals was the prominent species for Ebenaceae and for family Clusiaceae Calophyllum brasiliense, with 41 individuals. Several authors (FELFILI, 1994; SILVA JÚNIOR, 1999; NÓBREGA et al., 2001; SILVA et al., 2002) cite Fabaceae as the richest family found in vegetation formations of Central Brazil. They attribute this to the family's 
wide distribution range and ecological adaptability. As for areas dominated by Atlantic Forest, Fabaceae and Myrtaceae are also cited in most of the studies (MORI et al., 1983; SILVA e NASCIMENTO, 2001; MARTINS et al., 2002; PEIXOTO et al., 2004) as richest in species.

As for the successional classification of the most abundant species for the two fragments, Sclerolobium paniculatum var. rubiginosum and Cecropia pachystachya are considered pioneers and Calophyllum brasiliens are considered late secondary. Byrsonima intermedia and Qualea multiflora are heliophytes typical of Brazilian cerrados.

Table 2 - Families and species identified in a floristic survey at Lago Verde Farm, Lagoa da Confusão in Tocantins, Brazil. A: seasonally inundated forest in a rice cultivation region; B: flooded forest in intact (unaltered) region

Tabela 2 - Famílias e espécies identificadas no levantamento florístico realizado na Fazenda Lago Verde, Lagoa da Confusão, TO. A: floresta inundável em área antropizada; B: floresta inundável em área preservada

\begin{tabular}{|c|c|c|}
\hline Family/Species & A & B \\
\hline \multicolumn{3}{|l|}{ ANACARDIACEAE } \\
\hline Myracrodruon urundeuva Allemao & $\mathrm{x}$ & \\
\hline Tapirira obtusa (Benth.) D.J. Mitch. & $\mathrm{x}$ & $\mathrm{x}$ \\
\hline \multicolumn{3}{|l|}{ ANNONACEAE } \\
\hline Duguetia furfuracea (A. St.-Hil.) Saff. & & $\mathrm{x}$ \\
\hline Duguetia megalocarpa Maas & $\mathrm{x}$ & \\
\hline Guatteria pubens (Mart.) & $\mathrm{x}$ & \\
\hline \multicolumn{3}{|l|}{ R.E.Fr. det. J.E. Simonis } \\
\hline Xylopia aromatica (Lam.) Mart. & $\mathrm{x}$ & \\
\hline Xilopia sericea A. St.-Hil. & $\mathrm{x}$ & \\
\hline \multicolumn{3}{|l|}{ APOCYNACEAE } \\
\hline $\begin{array}{l}\text { Aspidosperma subincanum Mart. } \\
\text { Himatanthus lancifolius } \\
\text { (Müll. Arg.) Woodson }\end{array}$ & $\mathrm{x}$ & $\mathrm{x}$ \\
\hline \multicolumn{3}{|l|}{ AQUIFOLIACEAE } \\
\hline Ilex affinis Gardner & & $\mathrm{x}$ \\
\hline \multicolumn{3}{|l|}{ ARECACEAE } \\
\hline $\begin{array}{l}\text { Astrocaryum vulgare Mart. } \\
\text { Mauritiella armata (Mart.) Burret }\end{array}$ & $\mathrm{x}$ & $\begin{array}{l}x \\
x\end{array}$ \\
\hline Syagrus cocoides Mart. & $\mathrm{x}$ & $\mathrm{x}$ \\
\hline \multicolumn{3}{|l|}{ BIGNONIACEAE } \\
\hline Jacaranda brasiliana (Lam.) Pers. & $\mathrm{x}$ & \\
\hline Tabebuia aurea (Silva Manso) & $\mathrm{x}$ & \\
\hline Benth. \& Hook. f. ex S. Moore & & \\
\hline Tabebuia serratifolia (Vahl) G. Nicholson & $\mathrm{x}$ & $\mathrm{x}$ \\
\hline
\end{tabular}

Of the 95 species sampled in the two fragments, 24 were common to both, 47 were exclusively found in altered region fragment, and 24 were exclusive for the intact region forest. Therefore, even though they characterize the same physiognomic type and are under similar hydrologic influences, the two forests present clearly distinct floristics. At Uberlândia, Minas Gerais, greater floristic richness was found in a human disturbed vereda compared to an intact one. In this case, the difference was attributed to the greater environmental heterogeneity. This diversity was produced by disturbances that had occurred in the otherwise uniform environmental structure (GUIMARÃES et al., 2002).

Table 2 - Cont.

Tabela 2 - Cont.

\begin{tabular}{|c|c|c|}
\hline Family/Species & A & B \\
\hline \multicolumn{3}{|l|}{ BORAGINACEAE } \\
\hline Cordia alliodora (Ruiz \& Pav.) Oken & $\mathrm{x}$ & \\
\hline \multicolumn{3}{|l|}{ BURSERACEAE } \\
\hline Protium heptaphyllum (Aubl.) Marchand & $\mathrm{x}$ & \\
\hline Protium grandifolium Engl. & $\mathrm{x}$ & \\
\hline \multicolumn{3}{|l|}{ CANNABACEAE } \\
\hline Cannabaceae sp. & $\mathrm{x}$ & \\
\hline \multicolumn{3}{|l|}{ CARYOCARACEAE } \\
\hline Caryocar villosum (Aubl.) Pers. & $\mathrm{x}$ & \\
\hline \multicolumn{3}{|l|}{ CHRYSOBALANACEAE } \\
\hline Hirtella glandulosa Spreng. & $\mathrm{x}$ & $\mathrm{x}$ \\
\hline Hirtella racemosa Lam. & $\mathrm{x}$ & $\mathrm{x}$ \\
\hline Licania apetala (E. Mey.) Fritsch & & $\mathrm{x}$ \\
\hline \multicolumn{3}{|l|}{ CLUSIACEAE } \\
\hline $\begin{array}{l}\text { Calophyllum brasiliense Cambess. } \\
\text { DILLENIACEAE }\end{array}$ & DILLENIACEAE & $\mathrm{x}$ \\
\hline Curatella americana $\mathrm{L}$. & $\mathrm{x}$ & $\mathrm{x}$ \\
\hline \multicolumn{3}{|l|}{ EBENACEAE } \\
\hline Diospyros guianensis (Aubl.) Gürke & & $\mathrm{x}$ \\
\hline Diospyros sericea A. DC. & $\mathrm{x}$ & \\
\hline \multicolumn{3}{|l|}{ ELAEOCARPACEAE } \\
\hline Sloanea garckeana K. Schum. & & $\mathrm{x}$ \\
\hline \multicolumn{3}{|l|}{ ERYTHROXYLACEAE } \\
\hline $\begin{array}{l}\text { Erythroxylum anguifugum Mart. } \\
\text { EUPHORBIACEAE }\end{array}$ & EUPHORBIACEAE & $\mathrm{x}$ \\
\hline Mabea occidentalis Benth. & & $\mathrm{x}$ \\
\hline Maprounea guianensis Aubl. & $\mathrm{x}$ & \\
\hline \multicolumn{3}{|l|}{ FABACEAE } \\
\hline Acosmium dasycarpum (Vogel) Yakovlev & $\mathrm{x}$ & \\
\hline Copaifera langsdorffii Desf. & $\mathrm{x}$ & $\mathrm{x}$ \\
\hline Dipteryx alata Vogel & $\mathrm{x}$ & $\mathrm{x}$ \\
\hline Hymenaea courbaril L. & $\mathrm{x}$ & \\
\hline Hymenaea stigonocarpa Mart. ex Hayne & & $\mathrm{x}$ \\
\hline
\end{tabular}


Table 2 - Cont.

Tabela 2 - Cont.

\begin{tabular}{|c|c|c|}
\hline Family/Species & A & $\mathrm{B}$ \\
\hline \multicolumn{3}{|l|}{ FABACEAE } \\
\hline \multicolumn{2}{|c|}{ Lonchocarpus campestris Mart. ex Benth. } & $\mathrm{x}$ \\
\hline Plathymenia reticulata Benth. & $\mathrm{x}$ & $\mathrm{x}$ \\
\hline \multicolumn{2}{|l|}{ Poecilanthe parviflora Benth. } & $\mathrm{x}$ \\
\hline Sclerolobium aureum (Tul.) Baill. & $\mathrm{x}$ & \\
\hline & rubiginosum (Mart. ex Tul.) Benth. \\
\hline \multicolumn{3}{|c|}{ Senna spectabilis (DC.) H.S. Irwin \& Barneby } \\
\hline Swartzia apetala Raddi & $\mathrm{x}$ & \\
\hline \multicolumn{2}{|l|}{$\begin{array}{l}\text { Swartzia macrostachya var. } \\
\text { macrostachya R.S. Cowan }\end{array}$} & $\mathrm{x}$ \\
\hline \multicolumn{3}{|l|}{ ICACINACEAE } \\
\hline Emmotum nitens (Benth.) Miers & $\mathrm{x}$ & $\mathrm{x}$ \\
\hline \multicolumn{2}{|l|}{ LACISTEMATACEAE } & \\
\hline \multicolumn{2}{|l|}{ Lacistema hasslerianum Chodat } & $\mathrm{x}$ \\
\hline \multicolumn{3}{|l|}{ LAMIACEAE } \\
\hline $\begin{array}{l}\text { Aegiphila lhotskiana Cham. } \\
\text { Vitex polygama Cham. }\end{array}$ & $\mathrm{x}$ & $\mathrm{x}$ \\
\hline \multicolumn{3}{|l|}{ LAURACEAE } \\
\hline Nectandra gardneri Meisn. & $\mathrm{x}$ & $\mathrm{x}$ \\
\hline Ocotea aciphylla (Nees) Mez & $\mathrm{x}$ & \\
\hline \multicolumn{3}{|l|}{ LECYTHIDACEAE } \\
\hline Eschweilera ovata (Cambess.) Miers & $\mathrm{x}$ & $\mathrm{x}$ \\
\hline \multicolumn{3}{|l|}{ LYTHRACEAE } \\
\hline Lafoensia pacari A. St.-Hil. & $\mathrm{x}$ & \\
\hline Physocalymma scaberrimum Pohl & $\mathrm{x}$ & \\
\hline \multicolumn{3}{|l|}{ MALPIGHIACEAE } \\
\hline Byrsonima indorum S. Moore & $\mathrm{x}$ & \\
\hline Byrsonima intermedia A. Juss. & $\mathrm{x}$ & $\mathrm{x}$ \\
\hline Byrsonima sp. & & $\mathrm{x}$ \\
\hline \multicolumn{3}{|l|}{ MALVACEAE } \\
\hline Apeiba tibourbou Aubl. & $\mathrm{x}$ & \\
\hline Ceiba sp. & $\mathrm{x}$ & \\
\hline \multicolumn{3}{|l|}{ MALVACEAE } \\
\hline Luehea divaricata Mart. & $\mathrm{x}$ & \\
\hline Luehea grandiflora Mart. & $\mathrm{x}$ & \\
\hline \multicolumn{3}{|l|}{ MELASTOMATACEAE } \\
\hline Bellucia grossularioides (L.) Triana & & $\mathrm{x}$ \\
\hline \multicolumn{3}{|l|}{ MELIACEAE } \\
\hline Trichilia hirta L. & $\mathrm{x}$ & \\
\hline Trichilia lepidota Mart. & $\mathrm{x}$ & \\
\hline Trichilia micrantha Benth. & $\mathrm{x}$ & \\
\hline \multicolumn{3}{|l|}{ MENISPERMACEAE } \\
\hline Abuta grandifolia (Mart.) Sandwith & & $\mathrm{x}$ \\
\hline \multicolumn{3}{|l|}{ MONIMIACEAE } \\
\hline \multirow{2}{*}{\multicolumn{3}{|c|}{$\begin{array}{l}\text { Siparuna glycycarpa (Ducke) } \\
\text { S. S. Renner \& Hausner }\end{array}$}} \\
\hline & & \\
\hline MORACEAE & & \\
\hline Sorocea guilleminiana Gaudich. & & $\mathrm{x}$ \\
\hline
\end{tabular}

Table 2 - Cont.

Tabela 2 - Cont.

\begin{tabular}{|c|c|c|}
\hline Family/Species & A & $\mathrm{B}$ \\
\hline \multicolumn{3}{|l|}{ MYRISTICACEAE } \\
\hline Virola sebifera Aubl. & $\mathrm{x}$ & $\mathrm{x}$ \\
\hline \multicolumn{3}{|l|}{ MYRSINACEAE } \\
\hline Cybianthus gardneri (A. DC.) G. Agostini & $\mathrm{x}$ & \\
\hline \multicolumn{3}{|l|}{ MYRTACEAE } \\
\hline Calycorectes psidiiflorus (O. Berg) Sobra & & $\mathrm{x}$ \\
\hline Calyptranthes concinna DC. & $\mathrm{x}$ & \\
\hline \multicolumn{3}{|l|}{ MYRTACEAE } \\
\hline Eugenia florida DC. & $\mathrm{x}$ & \\
\hline Myrcia fallax (Rich.) DC. & $\mathrm{x}$ & \\
\hline \multicolumn{3}{|l|}{ OCHNACEAE } \\
\hline \multicolumn{2}{|l|}{ OLACACEAE } & $\mathrm{x}$ \\
\hline Heisteria laxiflora Engl. & $\mathrm{x}$ & $\mathrm{x}$ \\
\hline \multicolumn{3}{|l|}{ PROTEACEAE } \\
\hline Roupala montana Aubl. & $\mathrm{x}$ & $\mathrm{x}$ \\
\hline \multicolumn{3}{|l|}{ RUBIACEAE } \\
\hline Guettarda viburnoides Cham. \& Schltdl. & $\mathrm{x}$ & $\mathrm{x}$ \\
\hline \multicolumn{3}{|l|}{ RUTACEAE } \\
\hline Galipea trifoliata Aubl. & & $\mathrm{x}$ \\
\hline Pilocarpus sp. Vahl & & $\mathrm{x}$ \\
\hline Zanthoxylum rhoifolium Lam. & $\mathrm{x}$ & \\
\hline Zanthoxylum riedelianum Engl. & $\mathrm{x}$ & \\
\hline \multicolumn{3}{|l|}{ SAPINDACEAE } \\
\hline Allophylus edulis & $\mathrm{x}$ & \\
\hline $\begin{array}{l}\text { (A. St.-Hil., Cambess. \& A. Juss.) Radlk. } \\
\text { Matayba elaeagnoides Radlk. }\end{array}$ & $\mathrm{x}$ & \\
\hline Matayba guianensis Aubl. & $\mathrm{x}$ & \\
\hline \multicolumn{3}{|l|}{ URTICACEAE } \\
\hline Cecropia pachystachya Trécul & $\mathrm{x}$ & $\mathrm{x}$ \\
\hline \multicolumn{3}{|l|}{ VOCHYSIACEAE } \\
\hline Callisthene fasciculata Mart. & $\mathrm{x}$ & \\
\hline Qualea dichotoma (Mart.) Warm. & $\mathrm{x}$ & \\
\hline Qualea grandiflora Mart. & $\mathrm{x}$ & \\
\hline Qualea multiflora Mart. & $\mathrm{x}$ & $\mathrm{x}$ \\
\hline Vochysia divergens Pohl & $\mathrm{x}$ & $\mathrm{x}$ \\
\hline Vochysia pyramidalis Mart. & & $\mathrm{x}$ \\
\hline Vochysia rufa Mart. & $\mathrm{x}$ & \\
\hline Unidentified & & $\mathrm{x}$ \\
\hline
\end{tabular}

DURIGAN et al. (2000) cites the occurrence of some species being related to a disturbance history or to some specificity of ciliary environments. This leads to an uneven distribution with many individuals in some sites and few in others, but not in a very restrictive manner. Among the species cited by these authors and also occurring in the two seasonally inundated Lagoa da Confusão forests are Tapirira obtusa, Matayba elaeagnoides, Protium heptaphyllum, Cecropia pachystachya and Copaifera langsdorffii. 
The values of H' = 0,806 (Shannon-Weaver) and $\mathrm{J}=3.44$ nats/individual (equability) for the rice cultivation region fragment are considered high compared to values $\left(H^{\prime}=0.761\right.$ and $J=2.97$ ) for the intact region fragment. The greater diversity in species for the altered region forest could also be attributed to improved soil fertility caused by liming and chemical fertilizer applications in adjoining rice fields.

\subsection{Floristic similarity}

Table 3 presents environmental and vegetative characteristics as well as sampling methods used for each selected study. The analysis of a similarity dendrogram by group average (Figure 1) shows that many groups were formed at a low level of similarity. This indicates small floristic similarity among all areas.
Despite this floristic heterogeneity, five groups could be identified in the cluster analysis. The first group (a2) differs from the rest (a1), having the lowest jaccard index. This group ( $\underline{\mathrm{a} 2}$ ) is composed of a seasonal floodplain forest at Marchantaria Island in the lower reach of the Solimões-Amazonas River (R) and the strip of higher floodplain forest located at Afuá in Pará (K). What these two areas have in common is that they both belong to the Amazon region. The outstanding characteristic of the Amazon is high precipitation levels (approximately 2,500 mm annually), and the fact that both Amazon forests are periodically inundated (floodplain forest - Table 3). The prominent species in this group, Calophyllum brasiliense (Clusiaceae) and Gustavia augusta (Lecythidaceae) are prone to occupy wet areas (typically the Amazon situation).

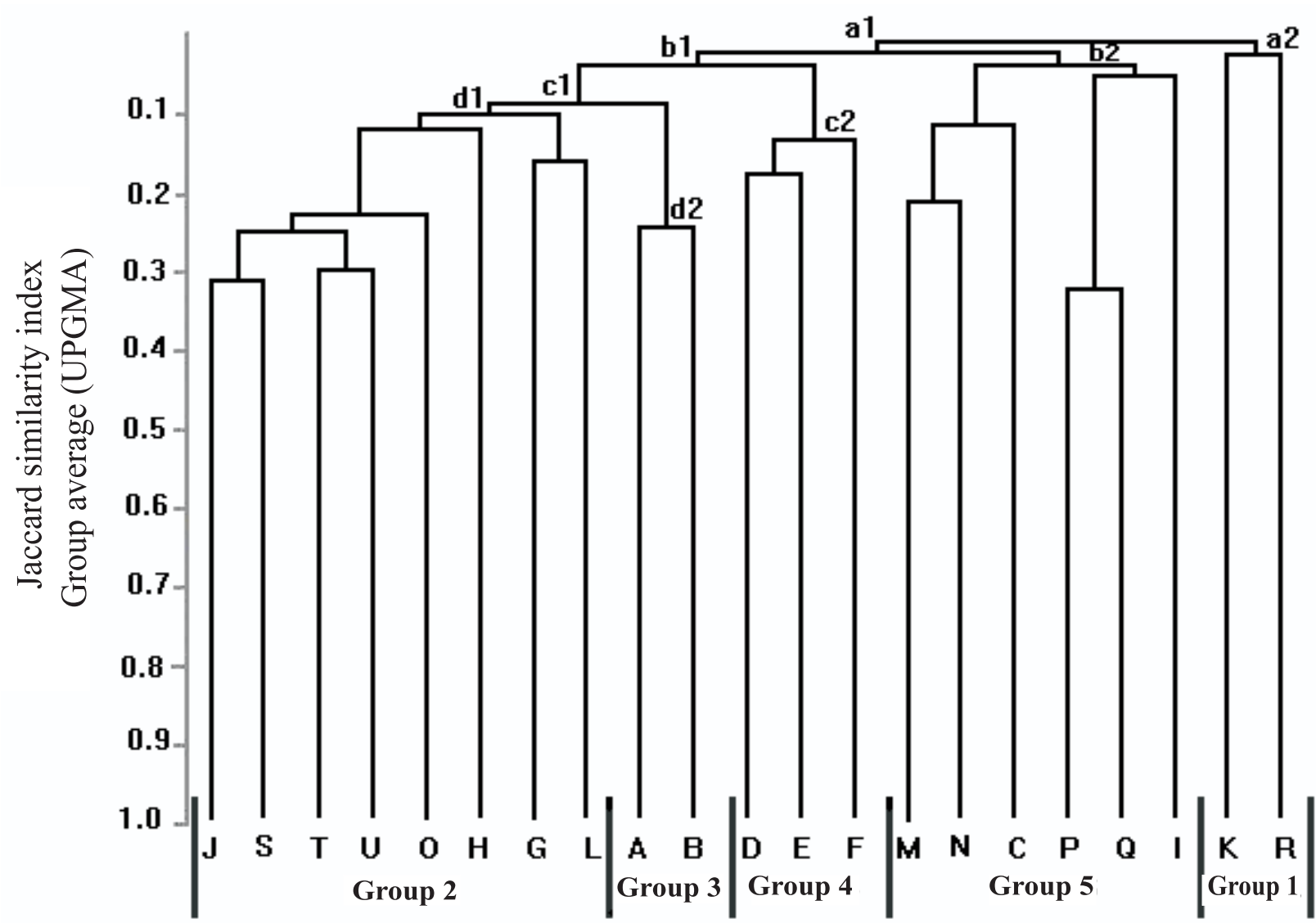

Figure 1 - Dendrogram displaying floristic similarity for ciliary, hydrophytic and seasonally inundated forests located in Northern, Central Western and Southeastern regions in Brazil.

Figura 1 - Dendrograma de similaridade florística entre florestas ciliares, higrófilas e inundáveis das Regiões Norte, CentroOeste e Sudeste. 


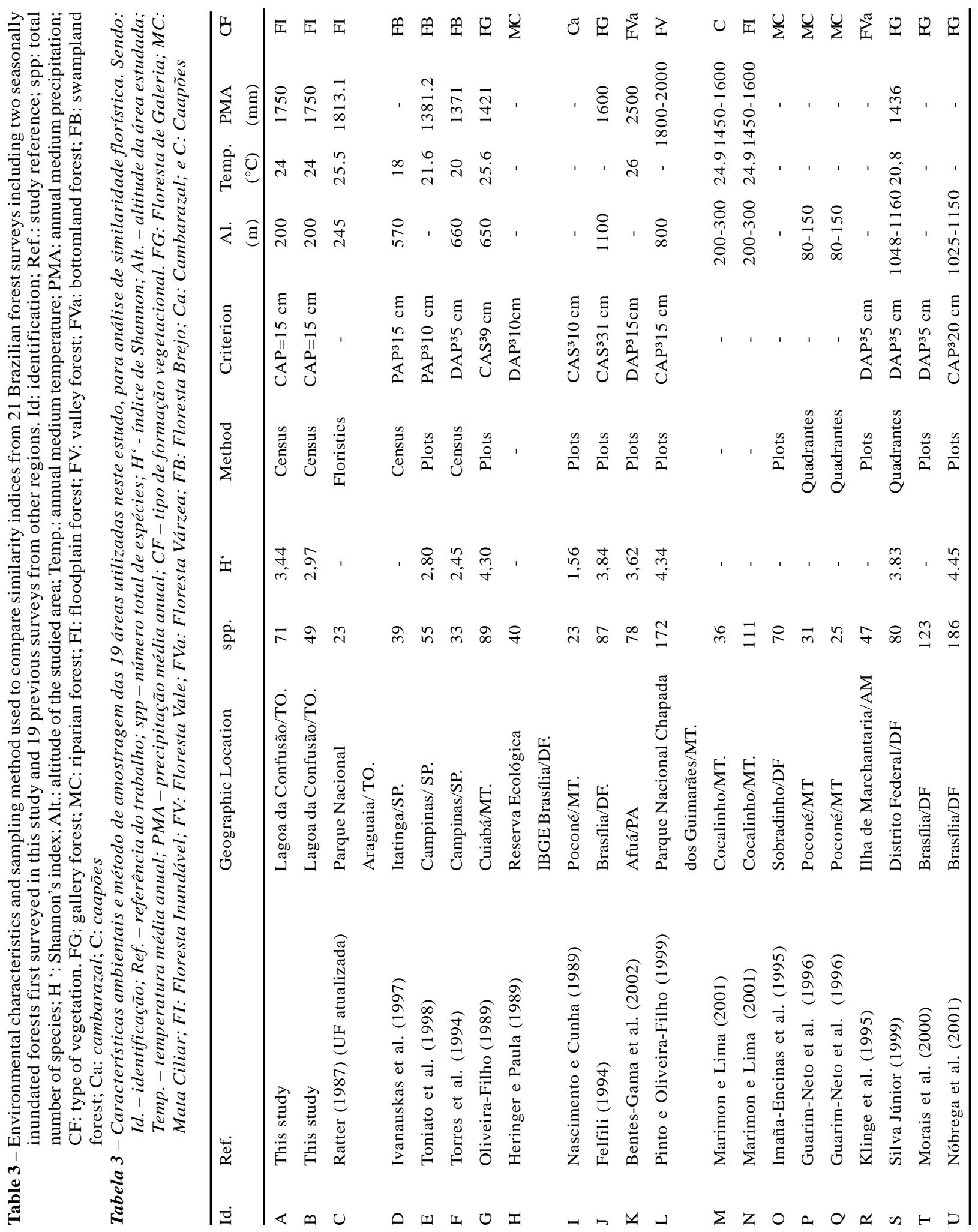


The second group ( $\underline{\mathrm{d} 1})$ is formed by strips of gallery forest alongside the Gama stream course in BrasíliaDF (J), the Monjolo gallery forest, located in the Brazilian Institute of Geography and Statistics (IBGE)/DF Ecological Reserve (S), the riparian Cabeça-de-Veado forest in the Botanical Garden of Brasília DF (U), the the ciliar forest Capãozinho Creek located at Sobradinho DF (O), the Jardim River headwaters gallery forest (T), the Roncador Branch riparian forest located at the IBGE Ecological Reserve in Brasília-DF (H), the valley forest at Chapada dos Guimarães National Park (Mato Grosso State) (L), and the Paciência Creek gallery forest at Cuiabá, Mato Grosso (G). A group subdivision occurred between Mato Grosso forest areas (L, M) and the Federal District (J, S, T, U, O, H). These areas have in common a climate characterized by dry winters and rainy summers. They also share the same general geographic location, all lying within Central Brazil Cerrado. If also observed in a more general context, the H' values for these areas could be considered high, indicating a high species diversity for these areas (Table 3). The floristic richness of Central Brazil's forests could be in part attributed to strong contributions coming from different vegetative typologies, especially from the Amazon and Atlantic forests and even including Caatinga. The great corridor formed by the Chaco, an extended plain located between the Central Plain of Brazil and the pre-Andean mountains (Walter, 1986) and the Steppe Savanna (Caatinga) contributes to the great floristic richness of this ecotonal region.

In this aspect, the floristic and structural profile of a valley forest in Chapada dos Guimarães National Park (Mato Grosso) (L) presented just as strong ties to Amazon as to Atlantic flora (sensu latu). This shows the transitional character of the arboreal community. The major floristic identity with these two environments could be related to the different methods adopted and to the extraordinary environmental heterogeneity at Chapada dos Guimarães (PINTO e OLIVEIRA-FILHO, 1999).

In group d1, Emmotum nitens (Icacinaceae) and Virola sebifera (Myristicaceae) were found in all forests. Matayba guianensis (Sapindaceae), Ouratea castaneifolia (Ochnaceae), Copaifera langsdorffii (Fabaceae), Maprounea guianensis (Euphorbiaceae), Hirtella glandulosa (Chrysobalanaceae), Cecropia pachystachya (Urticaceae) and Tapirira guianensis (Anacardiaceae) occurred in seven of the eight areas compared.
The main objects of this study, the two seasonally inundated forests in the Municipal District of Lagoa da Confusão-, Tocantins(A and B), one in an intact region and the other in an altered region, form a third group ( $\underline{\mathrm{d} 2})$. This is probably because of their geographic proximity, signaling their common characteristics, typical of natural fragments occurring in flood-susceptible topographic depressions. Another important fact observed was that even during a prolonged dry season, the soils in these seasonally inundated forests were still saturated, and the trees maintained their perennial foliage appearance. This evidence suggests that soil water availability is an important factor and certainly influences the floristic resemblance between the two natural fragments. Some of the species belonging to the fragments are considered generalists because they are found in both forests and cerrado. Examples are Maprounea guianensis and Copaifera langsdorffii. There are also species such as Vochysia pyramidalis that are prone toward more humid soils with range restricted to Central Brazil. Still others, such as Calophyllum brasiliense and Cecropia pachystachya, tend to occupy sites subject to long periods of flooding IVANAUSKAS et al., 1997; OLIVEIRA-FILHO and RATTER, 2000; LOBO and JOLY, 2000; MARTINS, 2001). Therefore, it is evident that the water resource input from streams or from rainfall - whatever floods these natural fragments - is an important ecological factor. Because of this water there are entire communities of species adapted to wet conditions that feature their own special structures and floristics. These provide food and shelter for associated wildlife. Thus, further studies must be carried out to investigate tolerance mechanisms of species to flooding. Much needs to be learned to adequately plan projects for recomposing areas that have suffered human intervention. More research is needed on surrounding riparian forests.

The two Lagoa da Confusão fragments were found to have Amazonian species such as Duguetia megalocarpa, Caryocar villosum, Licania apetala, Physocalymma scaberrimum and Bellucia grassularioides. At the same time, Atlantic Forest species were also present, including Poecilanthe parviflora, along wih cerrado species, including Dyospyros sericea, Erythroxylum anguifugum, Callisthene fasciculata, Qualea grandiflora and Qualea multiflora. Also identified were species that occur in two or three of those biomas, including Xylopia aromática, Himatanthus

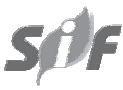

R. Árvore, Viçosa-MG, v.32, n.1, p.129-141, 2008 
lancifolius, Tabebuia serratifolia, Protium heptaphyllum, Maprounea guianensis, Hymenaea courbaril, Sorocea guilleminiana, Ouratea castaneifolia, Zanthoxylum rhoifolium, Allophyllus edulis, Matayba guianensis and Apeiba tibourbou. This diverse biome representation suggests that those seasonally inundated forest environments fit into a floristic profile classified as a transition zone (ecotone). Although this transition profile has its own particular characteristics, it is floristically more related to the group formed by gallery forests of the Central-Western Region (1ㅡ).

The three swampland forests in the state of São Paulo (D, E and F) constitute an isolated group (드). This was expected because of their geographic proximity and because they occupy areas with permanently waterlogged soils. This complete saturation conditions their floristic characteristic structures to be different from the ciliary zone forests. This greater soil humidity contributes to the selectiveness of species occurring in this formation. This is observed in their low diversity (Table 3) and is probably related to physiologic adaptability for resisting water saturation (IVANAUSKAS et al., 1997). Although they form a group isolated from the rest of the compared forests, the similarity among these three swampland forests was also small Such finding was also reported by Paschoal and Cavassan (1999), who compared these surveys with a Pelintra Creek swampland forest in Agudos- São Paulo. The authors explained that these differences could be attributed to varying levels of chemical elements and organic matter detected in the study. Other influences causing differences could be soil water saturation levels and surface water drainage patterns.

The fifth group (b2) contains strips of caapões (M), seasonally inundated forests growing in swamplands along the Rio das Mortes and Araguaia River in Cocalinho-,Mato Grosso (N), the seasonally inundated forest at the Araguaia National Park inTocantins(C), the ciliary forest strip of Cuiabá River in Mato Grosso (P), the ciliary forest stretch on the Bento Gomes River in Mato Grosso(Q) and Cambarazal in the Poconé swampland in Mato Grosso (I). Two common factors standing out for this group are altitude (200 m average) and annual rainfall (approximately $1600 \mathrm{~mm}$ ) (Table 3). Species that coincide in four of the six areas of this group are Calophyllum brasiliense, Amaioua guianensis and Vochysia divergens.

\section{R. Árvore, Viçosa-MG, v.32, n.1, p.129-141, 2008}

The most prominent species for the most of the compared forests in this study were Calophyllum brasiliense with 16 (76.2\%) occurrences in the 21 studies surveyed. This is an arboreal species linked to soil humidity conditions, and its range is from Central America to the northern coast of Santa Catarina, Brazil (OLIVEIRAFILHO and RATTER, 2000). Other prominent species were Cecropia pachystachya with 14 occurrences (66.7\%), Copaifera langsdorffii and Ouratea castaneifolia with 11 occurrences (52.4\%).

Comparing the results obtained for the seasonally inundated forests with those of other forests under direct hydrological influence shows that floristic composition differences exist among riparian forests in general (included in this group are gallery, ciliary and riparian forests), seasonally inundated forests and swampland forests. These differences result from the environmental heterogeneity caused by the distinct evolutions for different landscapes. These, in turn, condition differentiated environmental factor performances (IVANAUSKAS et al., 1997; SILVAJÚNIOR et al., 1998; RODRIGUES and NAVE, 2000; RODRIGUES and SHEPHERD, 2000).

The floristic separation of the seasonally inundated forests at Lagoa da Confusão in Tocantins from the other surveyed forests, and the presence of representative cerrado species in the Amazonian Forest and swampland forest biomes underlines the importance of conserving such natural fragments. The presence of those fragments in large, open landscapes, be they Gramineous-Woody Cerrado or rice fields, should favor wildlife. Even though occurring as islands, they still act as connecting links between riparian forests and remainders of the Forested Savanna, still abundant in the region.

\section{REFERENCES}

ANGIOSPERM PHYLOGENY GROUP - APG II. An update of the Angiosperm Phylogeny Group classification for the orders and families of flowering plants: APG II. Botanical Journal of the Linnean Society, v.141, p.399-436, 2003.

BENTES-GAMA, M.M. et al. Estrutura e valoração de uma floresta de várzea alta na Amazônia. Cerne, v.8, n.1, p.88-102, 2002. 
DURIGAN, G.; RODRIGUES, R.R.; SCHIAVINI, I. A heterogeneidade ambiental definindo a metodologia de amostragem da floresta ciliar. In: RODRIGUES, R.R.; LEITÃO FILHO, H.F. (Eds.). Matas ciliares: conservação e recuperação. São Paulo: Universidade de São Paulo e Fapesp, 2000. p.159-167.

EITEN, G. Vegetation near Santa Teresinha, NE Mato Grosso. Acta Amazônica, v.15, n.3/4, p.275-301, 1985.

EITEN, G. Vegetação dos cerrados. In: SEMATEC (Ed.) Cerrado: caracterização, ocupação e perspectivas. Brasília: Universidade de Brasília, 1994. p.9-65.

\section{EMPRESA BRASILEIRA DE PESQUISA} AGROPECUÁRIA - EMBRAPA. Centro Nacional de Pesquisa de Solos. Manual de métodos de análises de solo. 2.ed. Rio de Janeiro:1979. 212p.

FELFILI, J. M. et al. Análise comparativa da florística e fitossociologia da vegetação arbórea do cerrado sensu stricto na Chapada da Pratinha, DF- Brasil. Acta Botanica Brasilica, v.6, n.1, p.27-46, 1993.

FELFILI, J. M. Floristic composition and phytosociology of the gallery forest alongside the Gama stream in Brasília, DF, Brazil. Revista Brasileira de Botânica, v.17, n.1, p.1-11, 1994.

GUARIM-NETO, G. et al. Fitossociologia de matas ciliares no Pantanal Mato-Grossense. Boletim do Museu Paraense Emílio Goeldi, v.12, p.251-263, 1996.

GUIMARÃES, A. J. M.; ARAÚJO, G. M.; CORRÊA, G. F. Estrutura fitossociológica em área natural e antropizada de uma vereda em Uberlândia, MG. Acta Botanica Brasílica, v.16, n.3, p.317-329, 2002.

HERINGER, E. P.; PAULA, J. E. Contribuição para o conhecimento ecodendrométrico de matas ripárias da região Centro-Oeste Brasileira. Acta Botanica Brasílica, v.3, n.1, p.33-42, 1989.
IVANAUSKAS, N. M.; RODRIGUES, R. R.; NAVE, A. G. Aspectos ecológicos de um trecho de Florestas de Brejo em Itatinga, SP: florística, fitossociologia e seletividade de espécies.

Revista Brasileira de Botânica, v.20, n.1, p.139-153, 1997.

KLINGE, H.; ADIS, J.; WORBES, M. The vegetation of a seasonal várzea forest in the lower Solimões river, Brazilian Amazonia. Acta Amazônica, v.25, n.3/4, p.201-220, 1995.

LOBO, P. C.; JOLY, C. A. Aspectos ecofisiológicos da vegetação de mata ciliar do sudeste do Brasil. In: RODRIGUES, R.R.; LEITÃO FILHO, H. F. (Eds.). Matas ciliares: conservação e recuperação. São Paulo: Universidade de São Paulo e Fapesp, 2000. p.143-157.

MARIMON, B. S.; LIMA, E. S..Caracterização fitofisionômica e levantamento florístico preliminar no Pantanal dos Rios Mortes -Araguaia, Cocalinho, Mato Grosso, Brasil. Acta Botanica Brasílica, v.15, n.2, p.213-229, 2001

MARTINS, S. V.; COUTINHO, M. P.; MARANGON, L. C. Composição florística e estrutura de uma Floresta Secundária no município de Cruzeiro-SP. Revista Árvore, v.26, n.1, p.35-41, 2002.

MARTINS, S. V. Recuperação de matas ciliares. Viçosa, MG: Aprenda Fácil, 2001. 146p.

MARTINS, I. C. M. et al. Diagnóstico ambiental no contexto da paisagem de fragmentos florestais naturais “ipucas” - no Município de Lagoa da Confusão, Tocantins. Revista Árvore, v.26, n.3, p.299-309, 2002.

MILESKI, E. Aspecto da vegetação e do ecossistema da Ilha do Bananal: mapa fitoecológico e indicadores da pressão antrópica. Brasília: Gráfica da Secretária de Assuntos Estratégicos, 1994. 104p.

MORAIS, R. O.; IMAÑA-ENCINAS, J.; RIBEIRO, J. F. Fitossociologia da mata de galeria da cabeceira do rio Jardim, DF. Boletim do Herbário Ezechias Paulo Heringer, v.5, n.1, p.44-61, 2000.

R. Árvore, Viçosa-MG, v.32, n.1, p.129-141, 2008 
MORI, S. A. et al. Ecological importance of Myrtaceae in Eastern Brazilian wet forest. Biotropica, v.15, n.1, p.68-70, 1983.

MUELLER-DOMBOIS, D. Y.; ELLENBERG, M. Aims and methods in vegetation ecology. New York: Willey \& Sons, 1974. 547p.

NASCIMENTO, M. T.; CUNHA, C. T. Estrutura e composição florística de um cambarazal no Pantanal de Poconé-MT. Acta Botanica Brasílica, v.3, n.1, p.3-23, 1989.

NÓBREGA, M. G. G.; RAMOS, A. E.; SILVA JÚNIOR, M. C. Composição florística e estrutura na mata de galeria do Cabeça-de-Veado no Jardim Botânico de Brasília - DF. Boletim do Herbário Ezechias Paulo Heringer, v.8, n.1, p.44-65, 2001.

OLIVEIRA-FILHO, A. T. Composição florística e estrutura comunitária da floresta de galeria do Córrego da Paciência, Cuiabá (MT). Acta Botanica Brasílica, v.3, n.1, p.91-111, 1989.

OLIVEIRA-FILHO, A. T.; RATTER, J. A. Padrões florísticos das matas ciliares da região do Cerrado e a evolução das paisagens do Brasil Central durante o quaternário tardio. In: RODRIGUES, R. R.; LEITÃO FILHO, H. F. (Eds.). Matas ciliares: conservação e recuperação. São Paulo: Universidade de São Paulo e Fapesp, 2000. p.91-101.

PASCHOAL, M. E. S.; CAVASSAN, O. A flora arbórea da mata de brejo do ribeirão Pelintra, Agudos, SP. Naturalia, v.24, n.1, p.172-191, 1999.

PEIXOTO, G. L. et al. Composição florística do componente arbóreo de um trecho de Floresta Atlântica na Área de Proteção Ambiental da Serra da Capoeira Grande, Rio de Janeiro, RJ, Brasil. Acta Botanica Brasílica, v.18, n.1,p.151-160, 2004.

PIELOU, E. C. The interpretation of ecological data. New York: John Wiley \& Sons, 1975. 263p.

R. Árvore, Viçosa-MG, v.32, n.1, p.129-141, 2008
PINTO, J. R. R.; OLIVEIRA-FILHO, A. T. Perfil florístico e estrutura da comunidade arbórea de uma floresta de vale no Parque Nacional da Chapada dos Guimarães, Mato Grosso, Brasil. Revista Brasileira de Botânica, v.22, n.1, p.53-67, 1999.

RADAMBRASIL. Tocantins: levantamento de recursos naturais. Rio de Janeiro: Ministério das Minas e Energia, 1981.

RATTER, J. A. Notes on the vegetation of the Parque Nacional do Araguaia (Brazil). Notes Royal Botanic Garden, v.44, n.2, p.311-342, 1987.

RATTER, J. A.; RIBEIRO, J. F.; BRIDGEWATER, $\mathrm{S}$. The Brazilian Cerrado vegetation and threats to its biodiversity. Annals of Botany, v.80, n.3, p.223-230, 1997.

RIZZO, J. A. Flora do Estado de Goiás: plano de coleção. Goiânia: Universidade Federal de Goiás, 1981. 35p.

RODRIGUES, R. R.; NAVE, A. G. Heterogeneidade florística das matas ciliares. In: RODRIGUES, R. R.; LEITÃO FILHO, H. F. (Eds.). Matas ciliares: conservação e recuperação. São Paulo: Universidade de São Paulo e Fapesp, 2000. p.45-71.

RODRIGUES, R. R.; SHEPHERD, G. J. Fatores condicionantes da vegetação ciliar. In: RODRIGUES, R. R.; LEITÃO FILHO, H. F. (Eds.). Matas ciliares: conservação e recuperação. São Paulo: Universidade de São Paulo e Fapesp, 2000. p.101-107.

\section{SEPLAN/TO. Atlas do Tocantins:}

subsídios ao planejamento da gestão territorial. Palmas, Secretaria do Planejamento e Meio Ambiente, Diretoria de Zoneamento EcológicoEconômico, 2002.

SHEPHERD, G. J. Fitopac 1: manual do usuário. Campinas: Departamento de Botânica, UNICAMP, 1996. s/p.

SILVA JÚNIOR, M. C.; NOGUEIRA, P. E.; FELFILI, J. M. Flora lenhosa das matas de galeria no Brasil Central. Boletim do Herbário Ezechias Paulo Heringer, v.5, n.1, p.57-76, 1998. 
SILVAJÚNIOR, M. C. Composição florística, fitossociologia e estrutura diamétrica na mata de galeria do Monjolo, Reserva Ecológica do IBGE (RECOR), DF. Boletim do Herbário Ezechias Paulo Heringer, v.4, n.1, p.30-45, 1999.

SILVA, G. C.; NASCIMENTO, M. T.

Fitossociologia de um remanescente de mata sobre tabuleiros no norte do Estado do Rio de Janeiro (Mata do Carvão). Revista Brasileira de Botânica, v.24, n.1, p.51-62, 2001.

SILVA, L. O. et al. Levantamento florístico e fitossociológico em duas áreas de Cerrado sensu stricto no Parque Estadual da Serra de Caldas Novas, Goiás. Acta Botanica Brasílica, v.16, n.1, p.43-53, 2002.

SNEATH, P. H.; SOKAL, R. R. Numerical taxonomy. The principles and pratice of numerical classification. San Francisco: W.H. Freeman \&Company, 1973. 573p.
TONIATO, M. T. Z.; LEITÃO FILHO, H. F.; RODRIGUES, R. R. Fitossociologia de um remanescente de Floresta Higrófila (mata de brejo) em Campinas, SP. Revista Brasileira de Botânica, v.21, n.1, p.197-210, 1998.

TORRES, R. B.; MATHES, L. A. F.; RODRIGUES, R. R. Florística e estrutura do componente arbóreo de mata de brejo em Campinas, SP. Revista Brasileira de Botânica, v.17, n.1, p.189-194, 1994.

VELOSO, H. P.; RANGEL FILHO, A. L. T.; LIMA, J. C. A. Classificação da vegetação brasileira, adaptada a um sistema universal. Rio de Janeiro: IBGE, 1991. 124p.

WALTER, H. Vegetação e zonas

climáticas. São Paulo: Pedagógica e Universitária, 1986. 325p. 